\title{
Efficacity of ternidazole-neomycin sulfate-nystatin and prednisolone association in syndromic management of vaginitis in low and middle incomes countries
}

\author{
Déhi Boston Mian*, Védi André Serges Loué, Aya Virginie Angoi, Alexis Yao, Akinloye Sofia, \\ Koffi N'guessan, Serge Boni
}

Department of Gynecology and Obstetrics, University Hospital of Cocody, Abidjan, Cote d'Ivoire

Received: 20 January 2022

Accepted: 10 February 2022

\section{*Correspondence:}

Dr. Déhi Boston Mian,

E-mail: bostondehimian@yahoo.fr

Copyright: ( ) the author(s), publisher and licensee Medip Academy. This is an open-access article distributed under the terms of the Creative Commons Attribution Non-Commercial License, which permits unrestricted non-commercial use, distribution, and reproduction in any medium, provided the original work is properly cited.

\begin{abstract}
Background: Vaginitis is a frequent and treated based on clinical evaluation in our countries in absence of microbiological laboratories. Evaluate the effectiveness of the management of vaginitis by ternidazole, neomycin sulfate, nystatin, prednisolone association.

Methods: A five-month prospective study was carried out in three health facilities in Abidjan. Two-hundred and thirtythree patients with clinical signs of vaginitis were included after signed consent. Pregnant and breast-feeding patients, hypersensitivity or idiosyncrasy to ternidazole, neomycin sulfate, nystatin, prednisolone association were not included. Patients were divided into reference group $(n=200)$ for which a microbiological analysis of vaginal secretions was carried out 2-4 days before treatment and control group $(n=33)$ for which treatment was initiated straightaway. Evaluation criteria were clinical symptoms, microbiological balance carried out 10 to 14 days after treatment and occurrence of side effects. Statistical tests used were Khi2 and exact Fisher test $(\mathrm{p}<0.05)$.

Results: Pathological leucorrhoea was differently observed in both group $(\mathrm{p}=0.001)$. During the follow-up visit, the persistence of symptoms was not different $(\mathrm{p}=0.99)$. This combination has demonstrated its efficacy in cases of Candida albicans vaginitis, bacterial vaginosis, trichomonas vaginalis vaginitis, and mixed vaginitis. A significantly improvement of symptoms ( $\mathrm{p}=0.001)$ and low rate of biologically proven recurrence was observed in both groups. No allergic reactions linked was reported.

Conclusions: In our countries this therapeutic combination appears to be an option for treated mixed vaginitis in first intention without preliminary samples of vaginal secretions.
\end{abstract}

Keywords: Vulvovaginitis, Mycobacterial analysis, Ternidazole-neomycin sulfate-nystatin-prednisolone

\section{INTRODUCTION}

The vagina serves as an outside-communicating channel normally with unique flora that sustains the internal physical and chemical environment. the vagina is an ecosystem made up of several bacterial agents whose physiology depends on maintaining a balance between these different components. ${ }^{1}$ According to recent studies, the normal vaginal $\mathrm{pH}$ of women in reproductive activity is moderately acidic and is between 3.8 and 5..$^{2,3}$ Regarding the vaginal microbiome in particular, interest has been increasingly given to it in recent years, in order to guarantee well-being in women. ${ }^{4,5}$ The vaginal ecosystem is made up of billions of microbes coexisting in a homeostasis and mutualism relationship with its human host. The host provides a moist, nutritious and warm habitat for the microbes, while the resident microbiota produces antimicrobial and anti-inflammatory factors. ${ }^{6}$ 
This vaginal microbiota thus represents the first line of defense against non-indigenous microorganisms, but this balance can be broken by the conjunction of several internal and/or external factors. Some internal factors, such as hormonal status, age and immune system, altering the host environment impairs its ability to control opportunistic pathogens contained in resident microbes that could invade the human body and cause disease. External interferences, such as taking antibiotics, infectious pathologies and environmental microbial exposure, influence the vaginal microbiota, constituting potential risk factors for disease. ${ }^{7-12}$ The action of these internal and/or external factors leads to a disruption of the balance of the ecosystem, called dysbiosis.

DNA sequencing techniques have shown a limited association between the intestinal ecosystem and the occurrence of the disease, in contrast to the link between disturbances of the vaginal ecosystem and bacterial vaginosis $(\mathrm{BV}) .^{13,14}$

Furthermore, BV is said to trigger many health disorders including adverse pregnancy outcomes, human immunodeficiency virus (HIV), human papillomavirus (HPV), and pelvic inflammatory disease (PID).

Several studies have shown discrepancies between the frequencies of occurrence of lower genital infections, with first line bacterial vaginosis ( 8 to $75 \%$ ), followed by vaginal candidiasis $(2.2 \%)$ for and for trichomoniasis (0 to $34 \%) .{ }^{15-19}$ In our low incomes countries of sub-Saharan Africa, these low genital infections are generally underestimated because of the poverty of our statistics. In addition, etiological research is exceptional before starting treatment which very often is based on the data of the clinical examination due to the unavailability of laboratories for myco-parasito-bacteriological analyzes of vaginal secretions. This treatment is based on certain broad-spectrum therapeutic combinations comprising several local antiseptics (anti-bacterial, anti-parasitic, antimycotics). It is therefore to assess the effectiveness of our practice regarding the management of patients with vaginitis that we initiated this observational study. The main objective of the study was to assess the clinical efficacy of treatment with the combination ternidazole (anti-trichomonas)-neomycin (antibiotic)-nystatin (antifungal) -prednisolone (anti-inflammatory), administered in immediately in patients with signs of vaginitis. Secondary objectives were to assess the microbiological efficacy of this therapeutic combination, the correlation between efficacy on clinical symptoms and microbiological efficacy as well as tolerance.

\section{METHODS}

we carried out a multicentric, prospective, descriptive and analytical study which took place in the three university hospitals of Abidjan-Cote d'Ivoire (Cocody, Yopougon and Treichville) over a period of 5 months from January to May 2017.
Were included in the study two hundred and thirty-three (233) women aged 18 to 45 years with symptoms and signs of vulva and vaginal inflammation leading to the diagnosis of "vaginitis". Before their inclusion in the study, all patients received and read an information leaflet clearly explaining the benefits / risks of participating in this study and freely signed and dated two copies of informed consent attesting to their agreement participation. For the choice of treatment mode, the patients were randomized into two groups according to the order of presentation in consultation, were not retained for the study pregnant or breastfeeding women, co-infections, sexually transmitted infections, HIV infection, hypersensitivity or idiosyncrasy to the combination of ternidazole, neomycin sulfate, nystatin, prednisolone.

The course of the procedure included for all the patients, a thorough interrogation and gynecological examination (vulva examination, speculum placement and vaginal examination) which made it possible to suspect the diagnosis of vaginitis. Then patients were randomized into 2 groups for the treatment procedure.

The first group corresponded to the reference group which consisted of 4 subgroups of women. For the reference group, myco-bacterio-parasitological confirmation of vaginitis was obtained at the reference laboratory of university hospital of Cocody (Institute Pasteur) before starting treatment.

The second group was the control group, composed of patients who immediately received the local antiseptic treatment (combination of ternidazole, neomycin sulfate, nystatin, prednisolone) without any myco-bacterialparasitological analysis. In the short-term follow-up of patients in both groups, a myco-bacterial-parasitological examination was requested and a gynecological examination performed on admission 10 to 14 days later. The drug was in the form of a vaginal tablet and was administered vaginally at a dosage of 1 tablet once a day at bedtime for 10 days. Before the tablet is introduced into the vagina, it has been recommended to wet it in water for 2-3 seconds and insert it deep into the vagina.

The evaluation criteria were clinical and myco-parasitobacteriological characteristics at inclusion (presence or not of lactobacilli, various pathogenic groups such as Trichomonas, Mycoplasmas, easts, Staphylococci, Streptococcus, Escherichia coli, ...) and other opportunistic bacteria (anaerobic, Gardnerella vaginalis) of the vaginal flora, and finally the evolution of symptoms under short-term treatment (10 to 14 days). We also recorded the occurrence of side effects related to the use of the drug such as stinging or local irritation.

\section{Ethical approval}

Before starting the study, authorizations were obtained from the competent authorities, in particular the national 
ethics committee and the management of the various hospitals and the Pasteur institute.

Statistical analysis required the use of software EPI info 6.04, excel and word. The statistical tests used for the comparison of the numbers were Pearson's chi-square and Fisher's exact test with a significance level set at 5\% $(\mathrm{p}<0.05)$.

\section{RESULTS}

\section{General characteristics of patients on inclusion (Table 1)}

Reference group consisted $n=200$ women divide into 4 subgroups ( $\mathrm{SG}$ ) who received the treatment after mycoparasito-bacteriological diagnosis of vaginitis: $1^{\text {st }}$ subgroup (SG1): $\mathrm{n}=72$ women $(30.9 \%)$ with a diagnosis of Vulvovaginal candidiasis (VVC), $2^{\text {nd }}$ subgroup (SG2): $\mathrm{n}=30(12.9 \%)$ with bacterial vaginosis $(\mathrm{BV}), 3^{\text {rd }}$ subgroup (SG3): $n=34(14.6 \%)$ with a vaginitis trichomoniasis (VT), 4th subgroup (SG4): $n=64(27.5 \%)$ with mixed vaginitis (VM). Control group: $n=33$ women treated straight away without myco-parasito-bacteriological diagnosis (14.1\%).

\section{Symptoms reported at the inclusion visit before treatment with the combination ternidazole, neomycin sulfate, nystatin, prednisolone (Table 2)}

Before treatment, a significant difference was observed for pathological leucorrhoea between the reference group and the control group $(\mathrm{p}=0.001)$. These abnormal vaginal discharges were distributed differently in the different subgroups: (SG1: 91.7\%, SG2: 60\%, SG3: 64.7\%, SG4: $82.8 \%$, Control group: $57.6 \%$ ); The distribution of other symptoms before the treatment was not statistically different in the reference groups and the control group. The differences were in fact not significant for vulvar pruritus $(\mathrm{p}=0.99)$, uncomfortable and unpleasant sensations in the vulva $(\mathrm{p}=0.99)$, dyspareunia $(\mathrm{p}=0.06)$, urination burns $(p=0.99)$ and malodorous vaginal odor $(p=0.13)$. In the different subgroups, these symptoms were observed in the proportions specified in Tables 1 and 2: Vulvar pruritus (SG1: 97.2\%, SG2: 40\%, SG3: 58.8\%, SG4: 51.6\%, control group: 66.8\%); Uncomfortable and unpleasant sensations of the vulva (sensation of cooking) (SG1: 5.56\%, SG2: $10 \%$, SG3: 29.4\%, SG4: $28.1 \%$, Control group: 18.1\%); Dyspareunia (SG1: 6.9\%, SG2: 26.8\%, SG3: $23.5 \%$, SG4: 40.6\%, control group: $9.1 \%$ ); Voiding burns (SG1: $0.0 \%$, SG2: $0.0 \%$, SG3: $5.9 \%$, SG4: $1.6 \%$, control group: $0.0 \%$ ); Smelly vaginal odor (SG1: $1.4 \%$, SG2: $73.3 \%$, SG3: $14.7 \%$, SG4: $42.2 \%$, control group: $15.2 \%)$.

Abnormal vaginal discharge was statistically more observed in the reference groups compared to the control group $(\mathrm{p}=0.001)$

Symptoms reported at the follow-up visit after treatment with the combination (Table 3)
During the follow-up visit, 10 to 14 days after treatment, we observed a greater number of recurrences in the reference group without this difference being statistically significant $(\mathrm{p}=0.99)$. The main symptoms complained of all the women in our study at this check-up were: abnormal vaginal discharge in 4 women, i.e., 1.7\% (4/233), vulvar itching in 2 women, i.e., $0.9 \%$ (2/233), dyspareunia in 1 woman or $0.4 \%(1 / 233)$, foul-smelling vaginal odor in 2 women or $0.9 \%(2 / 233)$. This abnormal vaginal discharge corresponded to 1 woman $(1.4 \%)$ in the $1^{\text {st }}$ group; 1 woman $(3.3 \%)$ from the $2^{\text {nd }}$ group; 1 woman of the 3 rd group $(2.9 \%)$; 0 woman in the $4^{\text {th }}$ group and 1 woman $(3.0 \%)$ in the control group. Vulvar pruritus was detected in 1 woman of the $1^{\text {st }}(1.4 \%)$ and $3^{\text {rd }}(2.9 \%)$ groups and was not observed in any woman in the $2^{\text {nd }}, 4^{\text {th }}$ groups and the control group. Uncomfortable and unpleasant sensations of the vulva, and burning urination were not observed in the two groups. Dyspareunia was only present in 1 woman in the reference group. The smelly vaginal odor was found in 1 woman in group $3(2.9 \%)$ and in a woman in group 1 $(1.4 \%)$.

\section{Therapeutic efficacy and patient satisfaction (Tables 4 to 6)}

The evaluation of the effectiveness of the treatment and the presence of recurrences were carried out during the followup visit, 10 to 14 days after the start of the treatment, taking into account the dynamics of the evolution of the symptoms, of the clinic of disease and microbiological criteria obtained in the laboratory microbiological analysis of vaginal secretions, 10 to 14 days after treatment, made it possible to objectify the effectiveness of the treatment on bacterial and parasitic species. The recurrences concerned 1 case of VC, 1 case of BV, 3 cases of VT, 2 cases of MV in the reference group, i.e., a total of $3.5 \%$ ( 7 cases $/ 233)$.

\section{Recurrence also occurred in the control group (Table 5)}

The occurrence of a recurrence was not influenced by the way in which the treatment was prescribed $(p=0.99)$. To assess the effectiveness of the treatment, we also took into account other parameters, in particular: The time to symptom improvement, which was between the $3^{\text {rd }}$ and $4^{\text {th }}$ day after the start of treatment, with a significant difference in favor of the control group $(p=0.001)$. The time of symptom resolution which, without being statistically significant, was between the 4th and 5th day after the start of treatment ( $\mathrm{p}=0.07)$. In the control group, the bacterio-parasito-mycological control 10 to 14 days after the treatment was normal with a type I vaginal flora in 32 women $(97 \%)$. One case of recurrent vaginal candidiasis was diagnosed (Table 5). This suggests that the combination of ternidazole, neomycin sulfate, nystatin, prednisolone can be prescribed to women with obvious clinical signs of vaginitis, without predicting their etiologies, with very appreciable effectiveness (97\% cure rate). 
Table 1: General characteristics and symptoms of patients at inclusion before treatment.

\begin{tabular}{|c|c|c|c|c|c|c|}
\hline \multirow[b]{2}{*}{ Characteristics } & \multicolumn{4}{|c|}{ Reference groups } & \multirow{2}{*}{$\begin{array}{l}\text { Group } \\
\text { control, } \mathbf{n}=\mathbf{3 3} \\
(\%)\end{array}$} & \multirow[b]{2}{*}{ P value } \\
\hline & $\begin{array}{l}\text { VVC, } n=72 \\
(\%)\end{array}$ & $\begin{array}{l}\text { BV, } n=30 \\
(\%)\end{array}$ & $\begin{array}{l}\text { VT, n=34 } \\
(\%)\end{array}$ & $\begin{array}{l}\text { MV, n=64 } \\
(\%)\end{array}$ & & \\
\hline \multicolumn{7}{|l|}{ Socio-demographic } \\
\hline Age (Years \pm SD) & $28.45 \pm 8.43$ & $25.2 \pm 7.85$ & $25.97 \pm 8.26$ & $25.73 \pm 8.23$ & $25.06 \pm 11.29$ & $0.17(\mathrm{NS})$ \\
\hline Age (Years) & $12.16 \pm 1.43$ & $12.33 \pm 1.33$ & $12.47 \pm 1.6$ & $12 \pm 1.45$ & $10.63 \pm 3.65$ & $0.001(\mathrm{~S})$ \\
\hline $\begin{array}{l}\text { Pregnancies } \\
(\mathrm{n} \pm \mathrm{SD})\end{array}$ & $2.41 \pm 1.9$ & $1.6 \pm 2.04$ & $1.95 \pm 2.25$ & $1.95 \pm 2.25$ & $1.81 \pm 1.91$ & $0.70(\mathrm{NS})$ \\
\hline Deliveries $(\mathrm{n} \pm \mathrm{SD})$ & $1.62 \pm 1.64$ & $1.1 \pm 1.4$ & $1.3 \pm 1.64$ & $1.15 \pm 1.52$ & $11.18 \pm 1.48$ & $0.89(\mathrm{NS})$ \\
\hline \multicolumn{7}{|l|}{ Symptoms } \\
\hline Abnormal discharge & $66(91.8)$ & $18(60)$ & $22(64.7)$ & $53(82.8)$ & $19(57.6)$ & $0.001(\mathrm{~S})$ \\
\hline Vulvar ichting & $70(97.2)$ & $12(40)$ & $20(58.8)$ & $33(51.6)$ & $22(66.8)$ & $0.001(\mathrm{~S})$ \\
\hline Cooking sensation & $5.5(6)$ & $3(10)$ & $10(29.4)$ & $18(28.1)$ & $6(18.1)$ & $0.001(\mathrm{~S})$ \\
\hline Dyspareunia & $5(6.9)$ & $8(26.8)$ & $8(23.5)$ & $26(40.6)$ & $3(9.1)$ & $0.001(\mathrm{~S})$ \\
\hline Urination burns & $0(0)$ & $0(0)$ & $2(5.9)$ & $1(1.6)$ & $0(0)$ & Non valid \\
\hline Smelly vaginal odor & $1(1.4)$ & $22(73.3)$ & $5(14.7)$ & $27(42.2)$ & $05(15.2)$ & $0.001(\mathrm{~S})$ \\
\hline
\end{tabular}

S: Significant; NS: Not significant; ET $=$ Standard deviation; $*$ Candida albicans vaginitis; $* *$ Bacterial vaginosis.

Table 2: Main symptoms encountered according to the study groups during the inclusion visit.

\begin{tabular}{|llll|}
\hline Symptoms & Reference group, n (\%) & Control group n (\%) & P value \\
\hline $\begin{array}{l}\text { Pathological } \\
\text { Leucorrhoea }\end{array}$ & 159 & 19 & 0.001 (S) \\
\hline Vulvar itching & 135 & 22 & $0.99(\mathrm{NS})$ \\
\hline Vulvar burning & 35 & 6 & $0.99(\mathrm{NS})$ \\
\hline Pain with sexual & 47 & 3 & $0.06(\mathrm{NS})$ \\
\hline Dysuria & 3 & 0 & $0.99(\mathrm{NS})$ \\
\hline Smelly vaginal odour & 55 & 5 & $0.13(\mathrm{NS})$ \\
\hline
\end{tabular}

NS: Not significant.

Table 3: Comparison of the occurrence of recurrences 10 to 14 days after treatment.

\begin{tabular}{|lllll|}
\hline Recurrences & Reference group, $\mathbf{n}(\%)$ & Control group, $\mathbf{n}(\%)$ & Total & P value \\
\hline Yes & $7(3.5)$ & $1(3.03)$ & 8 & 0.99 (NS) \\
\hline No & $193(96.5)$ & $32(96.97)$ & 225 & \\
\hline Total & $200(100)$ & $33(100)$ & 233 & \\
\hline
\end{tabular}

NS: Not significant

Table 4: Efficacy results on symptoms 10 to 14 days after treatment.

\begin{tabular}{|llllll|}
\hline Symptoms & \multicolumn{2}{l}{ Reference groups } & & Group \\
control, $\mathbf{n = 1}$
\end{tabular}

S: Significant; NS: Not significant; ET = Standard deviation.

Table 5: Recurrence rate in the different groups after treatment.

\begin{tabular}{|lllllll|}
\hline Characteristics & \multicolumn{2}{l}{ Reference groups } & \multicolumn{3}{c|}{ Group } & P value \\
\hline $\begin{array}{l}\text { 10 to 14 days } \\
\text { after treatment }\end{array}$ & VVC & BV & VT & MV & control & \\
\hline
\end{tabular}


Table 6: Time to symptom progression and level of satisfaction according to the groups after treatment.

\begin{tabular}{|c|c|c|c|c|c|c|}
\hline \multirow{2}{*}{ Characteristics } & \multicolumn{4}{|c|}{ Reference groups } & \multirow{2}{*}{$\begin{array}{l}\text { Group } \\
\text { control }\end{array}$} & \multirow{2}{*}{ P value } \\
\hline & VVC & BV & VT & MV & & \\
\hline $\begin{array}{l}\text { Improvement period of } \\
\text { symptoms (days) }\end{array}$ & $3.23 \pm 1.8$ & $4.56 \pm 1.753$ & $3.32 \pm 2.18$ & $3.26 \pm 1.88$ & $2.58 \pm 1.66$ & $0.001(\mathrm{~S})$ \\
\hline $\begin{array}{l}\text { disappearance period } \\
\text { of symptoms (days) }\end{array}$ & $3.80 \pm 2.37$ & $3.16 \pm 2.84$ & $3.41 \pm 2.84$ & $3.89 \pm 2.63$ & $4.90 \pm 2.61$ & 0.07 (NS) \\
\hline Satisfaction of patient & $71(98.6 \%)$ & $30(100 \%)$ & $33(97.1 \%)$ & $64(100 \%)$ & $30(90.9 \%)$ & $\begin{array}{l}\text { Not } \\
\text { applicable }\end{array}$ \\
\hline
\end{tabular}

\section{DISCUSSION}

Vaginitis is a common disorder among women of varying ages, and most women have at least one episode of vaginitis during their lives. ${ }^{20}$ Vaginitis occurs because of the introduction of pathogens or changes in the vaginal environment that spread pathogens and change the vaginal flora. Vaginitis is caused by bacterial vaginosis, vulvovaginal candidiasis, or trichomoniasis. ${ }^{21}$ As the observations of DAN et al the present study showed that vaginitis caused by Candida albicans (VC) was the most frequent lower genital disorder in the reference group $(30.9 \%)$, for which a microbiological analysis of vaginal secretions had been performed before administering the treatment; followed by mixed vaginitis $(27.5 \%) .{ }^{19}$ For some authors, among all vaginitis cases, between $40 \%$ and $50 \%$ cases are caused by bacterial vaginosis, between $20 \%$ and $25 \%$ are caused by vulvovaginal candidiasis, and between $15 \%$ and $20 \%$ are caused by trichomoniasis. ${ }^{22}$ Characteristic symptoms, including discharge, odor, itching, irritation, and burning, produce discomfort or cause other vaginal complications. These symptoms are related to abnormal vaginal flora. ${ }^{23,24}$ Vulvovaginal complaints are one of the most common reasons for women to seek medical advice. ${ }^{25}$ The differential diagnosis of different types of vaginitis is difficult by symptoms or signs alone. Women with vulvovaginal candidiasis can even present a normal or acidic vaginal. ${ }^{22}$ Moreover, an inefficacious treatment with poor response may come after an inaccurate diagnosis with further potential sequelae, such as pelvic inflammatory disease. ${ }^{26,27}$ There are various signs and symptoms of vaginitis which suggest different types of vaginitis with other corresponding treatments in the clinical routine. ${ }^{28}$ However, in our context of under-medicalization, in the presence of difficulties in microbiological analysis of vaginal secretions, treatment based on syndromic management is frequently proposed..$^{29}$ The combination of ternidazole, neomycin sulfate, nystatin, prednisolone has demonstrated its therapeutic efficacy in cases of $\mathrm{CV}$, bacterial vaginosis (BV), Trichomonas vaginalis (TV), and even in mixed infection (VM). This efficacy was observed both clinically, with a significant and rapid improvement in symptoms within 3 to 4 days (significant difference in favor of the control group $\mathrm{p}=0.001$ ); but also, on the microbiological level with a biologically proven low recurrence rate in the two groups (3.4\%). Furthermore, there was no statistically significant difference in the occurrence of recurrence between the two groups $(\mathrm{p}=0.99)$. Thus, the combination of ternidazole, neomycin sulfate, nystatin, prednisolone could represent an interesting therapeutic option in women with obvious clinical signs of vaginitis, in the absence of prior microbiological analysis of vaginal secretions, with very effective appreciable (97\% cure rate). No adverse effects related to the combination of ternidazole, neomycin sulfate, nystatin, prednisolone occurred in this study.

Limitations of the study were the delay in obtaining the myco-bacterial-parasitological results, the difficulties in using the drug and in assessing the evolution of the symptoms.

\section{CONCLUSION}

This study showed that the combination of ternidazole, neomycin sulfate, nystatin, prednisolone could be administered to initiate treatment for vaginitis as soon as it appears without the need to take preliminary samples of vaginal secretions.

\section{Funding: No funding sources}

Conflict of interest: None declared

Ethical approval: The study was approved by the Institutional Ethics Committee

\section{REFERENCES}

1. Larsen B. Vaginal Flora in Health and Disease. Clin Obstetr Gynecol. 2017;36:107-21.

2. Carr PL, Felsenstein D, Friedman RH. Evaluation and management of vaginitis. J Gen Intern Med. 1998;13:335-46.

3. Murta EFC, Filho ACA. Barcelos ACM. Relation between vaginal and endocervical $\mathrm{pH}$ in pre-and postmenopausal women. Arch Gynecol Obstet. 2005;272 :211-3.

4. Ravel J, Gajer P, Abdo Z, Schneider GM, Koenig SS, McCulle SL et al. Vaginal microbiome of reproductive-age women. Proc Natl Acad Sci USA. 2011;108(1):4680-7.

5. Fettweis JM, Brooks JP, Serrano MG, Sheth NU, Girerd PH, Edwards DJ et al. Differences in vaginal microbiome in African American women versus 
women of European ancestry. Microbiology. 2017; 160:2272-82.

6. Chen C, Song X, Wei W, Zhong H, Dai J, Lan Z et al. The microbiota continuum along the female reproductive tract and its relation to uterine-related diseases. Nat Commun. 2017;8:875.

7. Pekmezovic M, Mogavero S, Naglik JR, Hube B. Host-pathogen interactions during female genital tract infections. Trends Microbiol. 2019;27;982-96.

8. Uchihashi M, Bergin IL, Bassis CM, Hashway SA, Chai D, Bell JD. Influence of age, reproductive cycling status, and menstruation on the vaginal microbiome in baboons (Papio anubis). Am J Primatol. 2015;77(5):563-78.

9. Ma B, Forney LJ, Ravel J. Vaginal microbiome: rethinking health and disease. Annu Rev Microbiol. 2012;66:371-89.

10. Dethlefsen L, Huse S, Sogin ML, Relman DA. The pervasive effects of an antibiotic on the human gut microbiota, as revealed by deep $16 \mathrm{~S}$ rRNA sequencing. PloS Biol. 2008;6:e280.

11. Lloyd-Price J, Arze C, Ananthakrishnan AN, Schirmer M, Avila-Pacheco J, Poon TW et al. Multiomics of the gut microbial ecosystem in inflammatory bowel diseases. Nature. 2019;569;655-62.

12. Shao Y, Forster SC, Tsaliki E, Vervier K, Strang A, Simpson N et al. Stunted microbiota and opportunistic pathogen colonization in caesarean section birth. Nature. 2019;574;117-21.

13. Manichanh C, Rigottier-Gois L, Bonnaud E, Gloux K, Pelletier E, Frangeul L et al. Reduced diversity of faecal microbiota in Crohn's disease revealed by a metagenomic approach. Gut. 2006;55;205-11.

14. Fredricks DN, Fiedler TL, Marrazzo JM. Molecular identification of bacteria associated with bacterial vaginosis. N Engl J Med. 2005;353:1899-911.

15. Konje JC, Otolorin EO, Ogunniyi JO, Obisesan KA, Ladipo OA. The prevalence of Gardnerella vaginalis, Trichomonas vaginalis and Candida albicans in the cytology clinic at Ibadan, Nigeria. Afr J Med Med Sci. 1991;20(1):29-34.

16. Mirza NB, Nsanze $H$, D'Costa LJ, Piot $P$. Microbiology of vaginal discharge in Nairobi, Kenya. Br J Vener Dis. 1983;59(3):186-8.
17. Ray A, Gulati AK, Pandey LK, Pandey S. Prevalence of common infective agents of vaginitis. J Commun Dis. 1989;21(3):241-4.

18. Hart G. Factors associated with trichomoniasis, candidiasis and bacterial vaginosis. Int J STD AIDS. 1993;4(1):21-5.

19. Dan M, Kaneti N, Levin D, Poch F, Samra Z. Vaginitis in a gynaecology practice in Israel: Causes and risk factors. IMAJ. 2003;5:629-32.

20. Sobel JD. Vaginitis. N Eng J Med. 1997;337:1896903.

21. Egan ME, Lipsky MS. Diagnosis of vaginitis. Am Fam Physician. 2000;62(5):1095-104.

22. Paladine HL, Desai UA. Vaginitis: Diagnosis and Treatment. Am Fam Physician. 2018;97(5):321-9.

23. ACOG Committee on Practice Bulletins-Gynecology. ACOG Practice Bulletin. Clinical management guidelines for obstetriciangynecologists, Number 72, May 2006: Vaginitis. Obstetr Gynecol. 2006;107(5):1195-1206.

24. Donders GG. Definition and classification of abnormal vaginal flora. Best Pract Res Clin Obstet Gynaecol. 2007;21(3):355-73.

25. Hainer BL, Gibson MV. Vaginitis. Am Fam Physician. 2011;83(7):807-15.

26. Schaaf VM, Perez-Stable EJ, Borchardt K. The Limited Value of Symptoms and Signs in the Diagnosis of Vaginal Infections. Arch Internal Med. 1990;150:1929-33.

27. Eschenbach DA, Hillier SL. Advances in diagnostic testing for vaginitis and cervicitis. J Reprod Med. 1989;34(8):555-64.

28. Lin YP, Chen WC, Cheng CM, Shen CJ. Vaginal pH Value for Clinical Diagnosis and Treatment of Common Vaginitis. Diagnostics (Basel). 2021;11(11):1996.

29. WHO-OMS 2008. Modules de formation pour la prise en charge syndromique des infections sexuellement transmissibles. 2008-ISBN9789242593402. Available at: https://www.who.int/reproductivehealth/publications /rtis/9789241593407/fr. Accessed on January 17, 2019.

Cite this article as: Mian DB, Loué VAS, Angoi AV, Yao A, Sofia A, N'guessan K et al. Efficacity of ternidazole-neomycin sulfate-nystatin and prednisolone association in syndromic management of vaginitis in low and middle incomes countries. Int J Reprod Contracept Obstet Gynecol 2022;11:670-5. 